\title{
ANALISIS KONTRIBUSI PAJAK RESTORAN TERHADAP PENDAPATAN PAJAK DAERAH PADA BADAN PENGELOLA PAJAK DAN RETRIBUSI DAERAH KABUPATEN MINAHASA SELATAN
}

\author{
Rachelyta Anugrahi ${ }^{1}$, Hendrik Manossoh ${ }^{2}$, Steven J. Tangkuman ${ }^{3}$ \\ 123 Jurusan Akuntansi, Fakultas Ekonomi dan Bisnis, Universitas Sam Ratulangi, Jl. Kampus Bahu, Manado, \\ 95115, Indonesia \\ Email : rchelaaa@gmail.com
}

\begin{abstract}
Restaurant Tax is one of the types of Regional Taxes. Regional Tax is a compulsory levy paid by a resident in a region to the local government of that place which will be used for the benefit of local government and public interest. The objective of this research is to know the contribution of Restaurant Tax to local tax revenue. This research uses descriptive qualitative method. The result of research shows that the contribution given by the improvement from 2014 is 5.13\%, and the next year 2015 is 8.74\%, then 2016 is $11.66 \%$, until 2017 is get 12.58\%. The effectiveness level of restaurant tax has fluctuated from 2014 to 2017.
\end{abstract}

Keywords: Contribution, Restaurant Tax, local Tax, Effectiveness

\section{PENDAHULUAN}

Kesejahteraan suatu daerah ditentukan juga dengan kondisi dan fasilitas daerah itu sendiri, maka dari itu pembangunan disuatu daerah sangat penting. Pemerintah disini bekerja untuk memperbaharui dan menyediakan fasilitas yang belum tersedia baik itu bidang politik, ekonomi, sosial, budaya, pertahanan dan keamanan. Dalam hal ini pemerintah tentunya membutuhkan dana tidak sedikit. Tujuan dari pembangunan ekonomi yang dilakukan pemerintah adalah untuk meningkatkan pendapatan nasional. Salah satu sumber penerimaan negara yang digunakan untuk pembangunan nasional adalah pajak. Pajak merupakan sumber pendapatan yang memberikan kontribusi terbesar dari semua potensi penerimaan negaran yang ada. Setiap iuaran yang dibayarkan oleh masyarakat semerta-merta tidak akan langsung dirasakan, seperti yang sudah dijelaskan dalam pasal 1 Undang-Undang Nomor 28 tahun 2007 tentang Ketentuan Umum dan Tata Cara Perpajakan adalah andil dari wajib pajak terhadap Negara yang terutang oleh Orang Pribadi (OP) atau Badan yang harus dan wajib dilakukan berdasarkan peraturan yang berlaku dengan tidak mendapat balasan secara langsung dan dipergunakan untuk kebutuhan Negara bagi sebesar-besarnya kemakmuran rakyat.

Membicarakan tentang pajak tidak akan terlepas dari kontribusi yang akan dihasilkan oleh pajak kepada perekonomian yang ada bukan hanya berdampak pada daerah itu saja tetapi kepada kemajuan perekonomian Indonesia. Sejak dulu bidang perbisnisan, pabrik dan industri menjadi aset utama dalam membantu perekonomian negara Indonesia hingga saat ini, karena hasil yang didapat dari bidang usaha tersebut dapat berguna tidak hanya beguna untuk negara sebagai pendapatan devisa negara dari pembayaran pajak yang dilakukan, tetapi juga pengusaha atau orang yang membuka usaha tersebut juga akan mendapatkan laba dari hasil usaha yang dibukanya dalam bidang perbisnisan, perindustrian, dan pabrik jadi tidak bisa dipungkiri bila banyak dari kalangan masyarakat yang menyukai untuk membuka usaha dibidang-bidang tersebut. Di Sulawesi Utara khususnya disini yaitu Minahasa Selatan, banyak sekali sumber-sumber yang dapat menyumbangkan pajak seperti tempat wisata, lokasi hiburan, hotel, dan usaha-usaha yang dapat menyumbang pajak salah satunya usaha membuka restoran. Di Kabupaten Minahasa Selatan terdapat 10 jenis Pajak Daerah salah 
satunya adalah Pajak Restoran yang termasuk dalam golongan pajak daerah yang memberikan kontribusi terbesar. Karena Kabupaten Minahasa Selatan juga merupakan salah satu tempat yang strategis dijalur darat yaitu trans Sulawesi, dan perkembangan yang ada di kabupaten ini terus meningkat membawa dampak yang baik pada Pendapatan Pajak Daerah di Minahasa Selatan. Di Kabupaten Minahasa Selatan restoran yang ada tiap tahun semakin menjamur dapat dilihat dari jumlah restoran yang ada dari tahun 2014 sampai 2017 sudah mencapai 93 restoran. Pembayaran pajak restoran sangat berdampak kepada pendapatan pajak yang akan mempengaruhi juga pada pendapatan asli daerah di Minahasa Selatan. Dengan perkembangan yang ada di daerah Minahasa Selatan baik dalam segini ekonomi bidang usaha-usaha yang ada membuat penulis tertarik untuk melakukan penelitian di tempat ini.

\section{TINJAUAN PUSTAKA}

Akuntansi Perpajakan. Subekti (2012: 1) menyatakan bahwa akuntansi perpajakan adalah proses merangkum dan menerangkan suatu kegiatan transaksi yang terjadi dalam satu usaha berdasarkan golongan jenis transaksi keuangan yang terjadi bertujuan untuk pemutusan dasar kewajiban (penghasilan kena pajak) yang harus dikeluarkan oleh badan usaha sebagai wajib pajak.

\section{Dasar-dasar Pajak}

Konsep Pajak. Mardiasmo (2011: 1) menyatakan pajak adalah pungutan yang diberikan kepada warga negara Indonesia bersifat terpaksa, tidak dapat langsung menikmati hasilnya melainkan digunakan untuk kepentingan umum.

Fungsi Pajak. Menurut Mardiasmo (2013: 1), fungsi pajak secara sederhana adalah untuk menyelenggarakan kepentingan bersama para warga masyarakat.

\section{Syarat Pemungutan Pajak}

a. Penarikan pajak harus merata (Syarat Keadilan).

b. Penarikan pajak harus sesuai dengan peraturan yang berlaku (Syarat Yuridis).

c. Tidak mengusik kegiatan perekonomian (Syarat Ekonomis).

d. Penarikan pajak harus sesuai.

e. Metode pemungutan pajak harus mudah.

\section{Hambatan Pemungutan Pajak}

a. Perlawanan pasif

b. Perlawanan aktif

Pengertian Pajak Daerah. Halim (2012 : 202), iuaran yang harus dibayar kepada wilayah yang terutang oleh OP dan atau badan yang harus dan wajib dibayar berdasarkan peraturan yang berlaku, dengan tidak mendapatkan balasan secara serta-merta tapi diperuntukkan bagi kebutuhan daerah untuk kesejahteraan rakyat merupakan pengertian dari pajak.

Kriteria Dan Ciri-Ciri Pajak Daerah. Siahaan (2006: 197) mengungkapkan bahwa dasardasar yang biasa digunakan perpajakan daerah yang benar tidak berbeda-beda, yaitu harus melengkapi tolak ukur yang berlaku sesuai dengan aturan perpajakan daerah.

Jenis Dan Tarif Pajak Daerah. Menurut Mardiasmo (2013:13) macam-macam pajak daerah serta biaya pajak daerah yang dapat diambil oleh pemerintah daerah sudah dikemas dalam Undang-undang Nomor 34 Tahun 2000, isi peraturan tersebut sebagai berikut:

a. Macam-macam dan biaya pajak yang ada di Provinsi adalah :

1. Pungutan atas alat transportasi roda dua dan alat transportasi diatas air sebesar $5 \%$ (lima persen);

2. Pajak penjualan alat transportasi roda dua dan alat transportasi diatas air sebesar $10 \%$ (sepuluh persen); 
3. Pungutan atas bahan bakar alat transportasi roda dua sebesar 5\% (lima persen);

4. Pungutan atas pengambilan dan penggunaan air permukaan dan air bawah tanah sebesar $20 \%$ (dua puluh persen).

b. Macam-macam dan biaya pajak Kabupaten atau Kota adalah :

1. $10 \%$ (sepuluh persen) untuk Pajak Hotel;

2. $10 \%$ (sepuluh persen) untuk Pajak Restoran;

3. $35 \%$ (tiga puluh lima persen) untuk Pajak Hiburan;

4. $25 \%$ (dua puluh lima persen) untuk Pajak Reklame;

5. $10 \%$ (sepuluh persen) untuk Pajak Penerangan Jalan;

6. 20\% (dua puluh persen) untuk Pajak Pengambilan Bahan Galian Golongan C;

7. Pajak Parkir 30\% (tiga puluh persen) untuk Pajak Parkir.

Pajak Restoran. Restoran merupakan tempat yang menyediakan pelayanan berupa makan dan atau minuman yang diambil bayaran, yang dalam hal ini meliputi rumah makan, catering atau jasa boga, kafetaria, kantin, warung, dan bar. Pajak Restoran dikenakan atas pelayanan yang diberikan oleh rumah makan atau restoran kepada pengunjung. Pajak Restoran seperti yang sudah disebutkan sebelumnya bahwa paling tinggi dikenakan $10 \%$.

Efektivitas Pajak. Menurut Mardiasmo (2002) efektivitas digunakan untuk menilai ikatan antara hasil dari pungutan suatu pajak dengan tujuan atau target yang telah ditetapkan. Efektivitas juga berkaitan dengan tingkat keberhasilan suatu aktivitas dibidang umum sehingga suatu kegiatan dikatakan efektif jika kegiatan tersebut mempunyai dampak yang besar atau dampak yang baik terhadap kemampuan menyediakan jasa masyarakat yang merupakan sasaran yang telah ditetapkan (Simanjuntak, 2001).

\section{METODE PENELITIAN}

Jenis Penelitian. Jenis penelitian yang digunakan dalam penelitian ini adalah jenis penelitian kualitatif deskriptif. Jenis penelitian ini menjelaskan secara sistematis mengenai kejadian yang sebenarnya, situasi dan aktivitas yang berkaitan tentang Analisis Kontribusi Pajak Restoran Terhadap Pajak Daerah Pada Badan Pengelola Pajak dan Retribusi Daerah Kabupaten Minahasa Selatan.

Tempat dan Waktu Penelitian. Lokasi penelitian ini dilakukan pada Badan Pengelola Pajak dan Retribusi Daerah (BPPRD) Kabupaten Minahasa Selatan. Periode dalam penelitian dilakukan pada tahun 2018 yaitu dimulai dari bulan Mei sampai dengan selesai.

\section{Jenis dan Sumber data}

Jenis Data. Secara umum, jenis data terbagi menjadi dua, yaitu data kualitatif dan kuantitatif

1. Data yang disajikan dalam bentuk uraian atau penjelasan yang diberikan berbentuk katakata merupakan jenis data kualitatif.

2. Data yang disajikan berbentuk angka-angka atau bilangan diolah atau dianalisis menggunakan teknik perhitungan matematika adalah jenis data kuantitatif.

Pada penelitian ini, jenis data yang digunakan oleh penulis adalah jenis data kualitatif yang bersifat deskriptif.

Sumber Data. Yang dipakai dalam penelitian ini adalah sumber data:

1. Data Primer. Data primer merupakan data yang didapat melalui survei dilapangan secara langsung. Data primer dalam penelitian ini yang diperoleh dengan cara meminta data-data yang diperlukan dan hasil dari wawancara.

2. Data Sekunder. Data sekunder merupakan data yang telah ada dan telah diterbitkan kepada masyarakat pengguna data. 
Teknik Pengumpulan Data. Adapun teknik yang digunakan dalam pengambilan data adalah sebagai berikut:

1. Dokumentasi. Pengambilan data dilakukan dengan mengumpulkan data mengenai halhal atau variabel yang dikaji. Data yang digunakan pada penelitian ini adalah data sekunder yang bersumber dari dokumen resmi Badan Pengelola Pajak dan Retribusi Daerah Kabupaten Minahasa Selatan.

2. Wawancara. Melakukan wawancara dengan pihak yang ada di Badan Pengelola Pajak dan Retribusi Daerah Kabupaten Minahasa Selatan untuk mendapatkan data yang diperlukan.

Metode Analisis Data. Kajian ini dilaksanakan secara terus menerus dari awal penelitian sampai dengan selesainya penelitian. Mulai dari memperoleh data dari hasil langsung dilapangan, hasil observasi, wawancara atau pun dokumentasi langsung dipelajari dan dirangkum dan dianalisis sampai selesai penelitian.

\section{HASIL PENELITIAN DAN PEMBAHASAN}

\subsection{Hasil Penelitian}

Deskripsi Pajak Restoran. Dasar Pengenaan Pajak adalah jumlah pembayaran yang harus dibayarkan konsumen kepada restoran. Dari jumlah tersebut dikalikan $10 \%$ yang merupakan tarif Pajak Restoran. Untuk pengenaan pajak dari restoran kita dapat menghitungnya dengan cara :

\section{Dasar Pengenaan Pajak $\times 10 \%$}

Jasa yang telah disiapkan oleh restoran merupakan pengertian dari Objek Pajak Restoran. Jasa yang dimaksud disini adalah pelayanan penjualan minuman dan atau makanan yang disantap oleh pembeli, baik dikonsumsi ditempat atau yang akan dibawa pulang. Bentukbentuk objek Pajak Restoran seperti : restoran, rumah makan, kafetaria, kantin, warung, depot, bar, food court, toko roti, dan jasa boga. Yang tidak termasuk alam objek pajak restoran adalah nilai penjualannya tidak melebihi jumlah Rp. 1.000.000,-/bulan.

Realisasi dan Target Pajak Restoran dari Tahun 2014-2017. Di daerah Tumpaan memiliki jumlah restoran yang paling banyak yaitu 13, disusul oleh daerah Buyungon dengan jumlah restoran 12, dengan urutan ke 3 dengan jumlah restoran 10 yaitu daerah Uwuran satu, selanjutnya Kapitu memiliki 9 restoran, lalu Sapa ada 7 restoran, menyusul Tompasobaru diurutan ke 6 dengan jumlah restoran 6, urutan ke 7 Kawangkoan Bawah dengan jumlah restoran 5, selanjutnya Bitung dengan jumlah restoran 4, lalu Ranoyapo dengan jumlah 3 restoran menduduki urutan ke 9, urutan ke 10 Radey, Uwuran Dua, Tawaang dengan jumlah 2 restoran, dan yang berada diurutan terakhir dengan jumlah restoran paling sedikit yaitu Matani, Ranomea, Lelema, Lewet, Uwuran, Teep, Pakuweru, Popontolen, dan Pondang, jumlah keselurahan hingga 2017 adalah 93 restoran meningkat dari tahun 2014 yaitu 60 restoran. 
Tabel 1. Realisasi Pajak Daerah Kabupaten Minahasa Selatan Tahun 2014-2017

\begin{tabular}{clrrrr}
\multicolumn{1}{c}{ Jenis Pajak } & \multicolumn{1}{c}{ (dalam Rp) } \\
\hline No. & \multicolumn{1}{c}{2014} & \multicolumn{1}{c}{2015} & 2016 & 241.420 .535 \\
\hline 1 & Pajak Hotel & 7.150 .000 & 19.429 .782 & 303.835 .088 & 241.45 \\
2 & Pajak Restoran & 451.414 .182 & 738.034 .259 & 1.275 .508 .289 & 1.545 .702 .942 \\
3 & Pajak Hiburan & 19.700 .000 & 34.875 .000 & 31.200 .000 & 69.500 .000 \\
4 & Pajak Reklame & 93.650 .000 & 170.197 .251 & 151.785 .000 & 241.988 .000 \\
5 & Pajak Penerangan Jalan & 4.394 .767 .360 & 4.831 .945 .337 & 4.683 .233 .508 & 5.974 .640 .012 \\
6 & Pajak Mineral Bukan Logam dan Batuan & 788.770 .000 & 1.027 .317 .480 & 1.267 .710 .800 & 1.176 .620 .793 \\
7 & Pajak Air Tanah & 13.589 .850 & 52.396 .800 & 166.500 .000 & 151.500 .000 \\
8 & Pajak Sarang Burung Wallet & - & 750.000 & 0 & 2.500 .000 \\
9 & Pajak Bumi dan Bangunan & 1.695 .412 .528 & 1.183 .675 .827 & 2.379 .297 .962 & 674.609 .264 \\
10 & Bea Perolehan Hak atas Tanah dan Bangunan & 1.331 .694 .363 & 892.507 .904 & 677.582 .769 & 2.202 .749 .860 \\
\hline \multicolumn{2}{l}{ Jumlah Pajak Daerah } & 8.796 .148 .283 & 8.951 .129 .640 & 10.936 .653 .416 & 12.281 .231 .406 \\
\hline
\end{tabular}

Sumber Data: BPPRD Kabupaten Minahasa Selatan

Dari tabel 2 pendapatan pajak dari tahun 2014 sampai tahun 2017 naik secara signifikan yaitu dari Rp. 451.414.182,- kemudian meningkat ditahun 2015 menjadi Rp. 738.034.259,-, lalu pada tahun 2016 menjadi Rp. 1.275.508.289,- dan terakhir pada tahun 2017 menjadi Rp. 1.545.702.942,-. Selisih dari tahun 2014 ke 2017 adalah Rp. 1.094.288.760,-. Pajak Restoran memberikan pemasukan yang baik tiap tahunnya terhadap pajak daerah, dan tidak mengalami fluktuasi dibandingkan dengan jenis pajak daerah lainnya. Dilihat dari data realisasi Pajak Daerah Kabupaten Minahasa Selatan, ada 9 jenis Pajak Daerah yang mengalami peningkatan serta penurunan pendapatan dari tahun 2014 hingga tahun 2017.

Tabel 2. Penetapan Pajak Daerah Kabupaten Minahasa Selatan Tahun 2014-2017

\begin{tabular}{llrrrr} 
& & & & & $($ dalam Rp) \\
\hline No & \multicolumn{1}{c}{ Jenis Pajak } & \multicolumn{1}{c}{2014} & \multicolumn{1}{c}{2015} & \multicolumn{1}{c}{2016} & 2017 \\
\hline 1 & Pajak Hotel & 18.000 .000 & 18.000 .000 & 27.000 .000 & 319.429 .782 \\
2 & Pajak Restoran & 200.000 .000 & 450.000 .000 & 559.434 .000 & 1.318 .034 .259 \\
3 & Pajak Hiburan & 28.000 .000 & 28.000 .000 & 28.000 .000 & 58.875 .000 \\
4 & Pajak Reklame & 160.000 .000 & 160.000 .000 & 160.000 .000 & 170.197 .251 \\
5 & Pajak Penerangan Jalan & 4.837 .200 .000 & 4.837 .200 .000 & 4.937 .200 .000 & 4.831 .945 .337 \\
6 & Pajak Mineral Bukan Logam dan Batuan & 486.800 .000 & 611.800 .000 & 986.800 .000 & 1.487 .317 .480 \\
7 & Pajak Air Tanah & 50.000 .000 & 50.000 .000 & 56.000 .000 & 138.976 .000 \\
8 & Pajak Sarang Burung Wallet & 20.000 .000 & 20.000 .000 & 20.000 .000 & 750.000 \\
9 & Pajak Bumi dan Bangunan & 2.500 .000 .000 & 3.000 .000 .000 & 2.500 .000 .000 & 520.000 .000 \\
10 & Bea Perolehan Hak atas Tanah dan Bangunan & 300.000 .000 & 550.000 .000 & 900.000 .000 & 2.710 .058 .444 \\
\hline Jumlah & 3.600 .000 .000 & 9.725 .000 .000 & 10.174 .434 .000 & 11.555 .583 .553 \\
\hline
\end{tabular}

Sumber Data: BPPRD Kabupaten Minahasa Selatan

Target yang diberikan pada Pajak Restoran terus meningkat tiap tahunnya, begitu juga dengan jumlah Pajak Daerah yang ditargetkan mengalami peningkatan. Jika dilihat pada tabel 4.2 realisasi dari penerimaan Pajak Restoran dari tahun 2014 sampai 2017 selalu mencapai bahkan melampaui target yang diberikan, dan penerimaan Pajak Restoran terbanyak terjadi pada tahun 2016 yaitu Rp. 1.275.508.289,- dengan target Rp. 559.434.000,-. Kalau dilihat dari penetapan jumlah Pajak Daerah yang diberikan tiap tahun mengalami peningkatan dari tahun 2014 yang berjumlah Rp. 3.600.000.000, tahun 2015 meningkat menjadi Rp. 9.725.000.000, tahun 2016 menjadi Rp. 10.174.434.000, dan terakhir tahun 2017 menjadi Rp. 11.555.583.553,-. Penetapan jumlah pajak daerah mengalami peningkatan terbesar pada tahun 2015, dari jumlah penetapan pajak pada tahun 2014 Rp. 3.600.000.000,- menjadi Rp. 9.725.000.000,-, tetapi pada tahun 2016 realisasi pajak daerah tidak mencapai target yang diberikan yaitu hanya mendapatkan Rp. 8.951.129.640,-. 


\subsection{Pembahasan}

Dalam penelitian ini kontribusi digunakan untuk melihat sejauh mana Pajak Restoran memberikan sumbangsih dalam penerimaan pendapatan Pajak Daerah. Untuk mengetahui kontribusi dilakukanlah perbandingan antara penerimaan Pajak Restoran periode tertentu dengan penerimaan Pajak Daerah periode tertentu. Mahmudi (2010 : 145) menyatakan hasil yang nanti akan didapat menentukan tingkat peranan Pajak Restoran terhadap pendapatan Pajak Daerah yang bila mana jika hasilnya besar berarti semakin besar pula peranan Pajak Restoran terhadap pendapatan Pajak Daerah, tetapi jika hasil perbandingannya kecil berarti peranan Pajak Restoran terhadap pendapatan Pajak Daerah kecil pula. Penerimaan Pajak Daerah dari tahun 2014 hingga 2017 yang terjadi di Kabupaten Minahasa Selatan mengalami peningkatan yang positif, setiap jenis pajak berdasarkan hasil data yang telah diterima memberikan kontribusi yang beraneka ragam jumlahnya dari yang terkecil hingga yang paling banyak. Kontribusi dari Pajak Restoran merupakan salah satu dari pajak yang dapat diandalkan oleh Kabupaten Minahasa Selatan.

Tabel 3. Kontribusi Pajak Restoran terhadap Pendapatan Pajak Kabupaten Minahasa Selatan Tahun 2014-2017

\begin{tabular}{ccrrc}
\hline Tahun & $\begin{array}{c}\text { Pajak Restoran } \\
(\mathbf{R p})\end{array}$ & $\begin{array}{c}\text { Pendapatan Pajak } \\
(\mathbf{R p})\end{array}$ & Kontribusi (\%) & Kriteria \\
\hline 2014 & 451.414 .182 & 8.796 .148 .283 & $5,13 \%$ & Sangat Kurang \\
2015 & 738.034 .259 & 8.951 .129 .640 & $8,74 \%$ & Sangat Kurang \\
2016 & 1.275 .508 .289 & 10.936 .653 .416 & $11,66 \%$ & Kurang \\
2017 & 1.545 .702 .942 & 12.281 .231 .406 & $12,58 \%$ & Kurang \\
\hline \multicolumn{5}{c}{ Rata-rata Kontribusi } \\
\hline
\end{tabular}

Sumber Data : BPPRD Kabupaten Minahasa Selatan (Diolah)

Kontribusi yang diberikan Pajak Restoran terhadap pendapatan pajak Daerah Kabupaten Minahasa Selatan dapat dilihat dalam tabel 4 yang merupakan data yang telah diolah, dan didapati mengalami peningkatan setiap tahunnya dari tahun 2014 yang berjumlah $5,13 \%$, tahun 2015 meningkat menjadi 8,74\% yaitu naik 3,61\% dari tahun 2014, tahun 2016 meningkat lagi menjadi 11,66\% meningkat 2,92\% dari tahun 2015, dan hingga tahun 2017 berjumlah 12,58\% meningkat lagi 0,92\% dari tahun 2016 yang juga merupakan kontribusi terbesar Pajak Restoran selama 4 tahun. Rata-rata yang didapat dari kontribusi secara keseluruhan dari tahun 2014 hingga 2017 Pajak Restoran memberikan kontribusi terhadap Pajak Daerah sebesar 9,52\%. Rumus yang dapat kita pakai untuk menghitung kontribusi pajak restoran terhadap Pajak Daerah ialah :

$$
\frac{\text { Realisasi Penerimaan Pajak Restoran }}{\text { Realisasi Penerimaan Pajak Daerah }} \text { X 100\% }
$$

Tabel 4. Kriteria Tingkat Kontribusi Pajak

\begin{tabular}{cc}
\hline Persentase Kontribusi & Kriteria \\
\hline $0,00 \%-10 \%$ & Sangat Kurang \\
$10,10 \%-20 \%$ & Kurang \\
$20,10 \%-30 \%$ & Sedang \\
$30,10 \%-40 \%$ & Cukup Baik \\
$40,10 \%-50 \%$ & Baik \\
$>50 \%$ & Sangat Baik \\
\hline
\end{tabular}

Sumber Data : Kepmendagri No 690.900.327 Tahun 2006 
Jika dilihat dari tabel 5 kontribusi yang diberikan oleh Pajak Restoran kepada Pajak Daerah termasuk dalam kategori kontribusi sangat kurang yaitu pada tahun 2014 dengan jumlah persentase 5,13\%, dan 2015 dengan jumlah persentase 8,74\%. Sedangkan untuk 2 tahun berikutnya termasuk dalam kategori kontribusi kurang yaitu tahun 2016 11,66\%, dan tahun 2017 dengan jumlah 12,58\%. Walaupun kontribusi Pajak Restoran terus mengalami peningkatan tetapi hasil dari perhitungan rata-rata yang diberikan oleh Pajak Restoran masih termasuk dalam kategori sangat kurang, yaitu dengan jumlah 9,52\%. Untuk mengetahui tingkat efektifitas Pajak Restoran terhadap Pajak Daerah kita akan menghitung dengan menggunakan rumus :

$$
\frac{\text { Realisasi Penerimaan Pajak Restoran }}{\text { Target Penerimaan Pajak Daerah }} \text { X 100\% }
$$

Untuk mengkategorikan tingkat efektivitas Pajak Restoran kedalam beberapa kriteria efektivitas dapat dilihat pada tabel berikut ini :

Tabel 5. Kriteria Tingkat Efektifitas

\begin{tabular}{cc}
\hline Persentasi Efektivitas & Kriteria \\
\hline Diatas $100 \%$ & Sangat Efektif \\
$90 \%-100 \%$ & Efektif \\
$80 \%-90 \%$ & Cukup Efektif \\
$60 \%-80 \%$ & Kurang Efektif \\
Kurang dari $60 \%$ & Tidak Efektif \\
\hline
\end{tabular}

Sumber Data : Kepmendagri No. 690.900.327 Tahun 2006

Dari tabel diatas kita bisa melihat ada 5 kategori yang dapat dibagikan dalam kriteria efektivitas, yaitu mulai dari katergori tidak efektif dari $0 \%$ hingga $60 \%$, kategori kurang efektif mulai dari 60,1\% hingga 80\%, kategori cukup efektif mulai dari 80,1\% hingga 90\%, kategori yang efektif $90,1 \%$ hingga $100 \%$, dan kategori yang terakhir sangat efektif diatas $100 \%$. Untuk menilai hubungan yang terjadi antara hasil yang didapat dari iuaran suatu pajak dengan target atau tujuan yang telah ditetapkan kita menggunakan efektivitas (Mardiasmo, 2002). Dari hasil estimasi yang dilakukan menggunakan rumus efektivitas Pajak Restoran mendapatkan hasil yang akan disajikan pada tabel dibawah ini :

Tabel 6. Efektivitas Pajak Restoran terhadap Pajak Daerah Kabupaten Minahasa Selatan Tahun 2014-2017

\begin{tabular}{ccccc}
\hline Tahun & $\begin{array}{c}\text { Pajak Restoran } \\
(\mathbf{R p})\end{array}$ & $\begin{array}{c}\text { Target Penerimaan } \\
\text { Pajak Restoran }(\mathbf{R p})\end{array}$ & $\begin{array}{c}\text { Persentase } \\
\text { Efektivitas }\end{array}$ & Kriteria Efektivitas \\
\hline 2014 & 451.414 .182 & 200.000 .000 & $225,7 \%$ & Sangat Efektif \\
2015 & 738.034 .259 & 450.000 .000 & $164 \%$ & Sangat Efektif \\
2016 & 1.275 .508 .289 & 559.434 .000 & $227 \%$ & Sangat Efektif \\
2017 & 1.545 .702 .942 & 1.318 .034 .259 & $117,27 \%$ & Sangat Efektif \\
\hline $\begin{array}{c}\text { RATA - } \\
\text { RATA }\end{array}$ & $\mathbf{1 . 0 0 2 . 6 6 4 . 9 1 8}$ & $\mathbf{6 3 1 . 8 6 7 . 0 6 5}$ & $\mathbf{1 8 3 . 4 9 \%}$ & Sangat Efektif \\
\hline
\end{tabular}

Sumber Data : BPPRD Kabupaten Minahasa Selatan (Diolah)

Sesuai dengan tabel 6 rata-rata efektivitas yang didapat dari tahun 2014 sampai 2017 adalah 183,49\% dan termasuk pada kategori sangat efektif. Pada tahun 2014 tingkat efektivitas sebesar 225,7\% yang juga merupakan tingkat efektivitas terbesar ke dua. Pada tahun 2015 tingkat efektivitas sebesar $164 \%$ mengalami penurunan dari tahun sebelumnya. Tahun 2016 
tingkat efektivitas sebesar $227 \%$ mengalami peningkatan $63 \%$ dari tahun sebelumnya dan merupakan persentase efektivitas terbesar dari tahun 2014-2017. Dan pada tahun 2017 tingkat efektivitas sebesar $117,27 \%$ mengalami penurunan kembali dari tahun sebelumnya tahun 2017 tapi walaupun mengalami fluktuatif, tingkat efektivitas pajak restoran dari tahun 2014 hingga tahun 2017 masih masuk dalam kategori sangat efektif. Menurut Abdul (2004) kemampuan daerah menjalankan tugas dikategorikan efektiv apabila rasio yang dicapai mencapai $100 \%$, sehingga semakin tinggi rasio efektivitas berarti menggambarkan kemampuan daerah yang semakin baik.

\section{KESIMPULAN DAN SARAN}

\subsection{Kesimpulan}

Berdasarkan hasil dari penelitian dan pembahasan yang telah diuraikan sebelumnya, maka diambil kesimpulan penelitian sebagai berikut ini :

1. Dari seluruh hasil data yang didapat, dan hasil perhitungan yang telah dilakukan dapat dilihat bahwa Pajak Restoran memberikan kontribusi yang termasuk dalam kategori sangat kurang terhadap Pajak Daerah, tetapi jika dilihat dari tingkat efektifitas Pajak Restoran memberikan dampak yang sangat efektif yaitu dapat dilihat pada hasil data yang diolah persentase menunjukkan dari tahun 2014-2017 selalu melebihi dari 100\%.

2. Kontribusi Pajak Restoran yang terbesar yaitu terjadi pada tahun 2017 yaitu penerimaan Pajak Restoran sebesar Rp. 1.545.702.942,- dengan pendapatan Pajak Daerah pada tahun itu sebesar Rp. 12.281.231.406,- dengan persentase kontribusi adalah 12,58\%, dan yang terendah pada tahun 2014 yaitu penerimaan Pajak Restoran sebesar Rp. 451.414.182,dengan pendapatan Pajak Daerah sebesar Rp. 8.796.148.285,- dengan persentase kontribusi adalah $5,13 \%$.

3. Penerimaan Pajak Restoran tiap tahun terus mengalami peningkatan yang signifikan dari tahun 2014 sampai dengan 2017 tidak mengalami fluktuatif.

4. Pajak Restoran dari tahun 2014 sampai 2017 selalu mencapai target penerimaan pajak yang ditetapkan.

\subsection{Saran}

Saran yang dapat diberikan peneliti berdasarkan hasil penelitian ini adalah :

1. Untuk mengubah kontribusi Pajak Restoran terhadap pendapatan Pajak Daerah yang saat ini masih termasuk dalam golongan sangat kurang adalah dengan membuka tempattempat makan didaerah pantai maupun ditempat kunjungan wisata, melakukan pemantauan di restoran/ rumah makan, dan mencatat atau menambahkan daftar tempat restoran yang sudah memenuhi kriteria yaitu berpenghasilan Rp 1.000.000,-/ bulan ke dalam objek pajak restoran di Kabupaten Minahasa Selatan.

2. Pemerintah Kabupaten Minahasa Selatan lebih khusus pada Badan Pengelola Pajak dan Retribusi Daerah untuk perlu meng-update website informasi agar dapat lebih mudah untuk diakses oleh masyarakat yang membutuhkan informasi, serta melakukan sosialisasi tentang pajak kepada masyarakat dan lebih meningkatkan pengawasan dan perhatian agar efektivitas pajak restoran tidak mengalami fluktuatif ditahun-tahun selanjutnya dan juga melakukan kegiatan-kegiatan seperti perayaan yang berhubungan dengan adat istiadat diMinahasa Selatan.

\section{DAFTAR PUSTAKA}

Agoes, Sukrisno dan Trisnawati, Estralia. 2010. Akuntansi Perpajakan. Edisi 2 Revisi. Salemba Empat. Jakarta.

Halim, Abdul. 2012. Pengelolaan Keuangan Daerah. Edisi Revisi. Bukubeta. Yogyakarta. Mardiasmo. 2002. Perpajakan. Edisi Revisi. Andi. Yogyakarta. 2011. Perpajakan. Edisi Revisi. Andi. Yogyakarta. 
2013. Perpajakan. Edisi Revisi. Andi. Yogyakarta.

Siahaan, Marihot. 2006. Pajak Daerah dan Retribusi Daerah. PT. Raja Grafindo Persada. Jakarta.

Persada. Jakarta.

Simanjuntak, Payaman. 2001. Pengantar Ekonomi Sumber Daya Manusia. LPFEUI. Jakarta.

Subekti, Wibowo. 2012. Akuntansi Perpajakan. Salemba Empat. Jakarta.

Undang-Undang Republik Indonesia Nomor 28 Tahun 2007 Ketentuan Umum dan Tata Cara Perpajakan. 17 Juli 2007. Lembaran Negara Republik Indonesia Tahun 2007 Nomor 85. Tambahan Lembaran Negara Republik Indonesia Nomor 4740. Jakarta.

Undang-Undang Republik Indonesia Nomor 28 Tahun 2009 Pajak Daerah dan Retribusi Daerah. 15 September 2009. Lembaran Negara Republik Indonesia Tahun 2009 Nomor 130. Tambahan Lembaran Negara Republik Indonesia Nomor 5049. Jakarta.

Undang-Undang Republik Indonesia Nomor 34 Tahun 2000 Pajak dan Retribusi Daerah. 20 Desember 2000. Lembaran Negara Republik Indonesia Tahun 2000 Nomor 246. Tambahan Lembaran Negara Republik Indonesia Nomor 4048. Jakarta. 